\title{
ANALISIS PELUANG PENGEMBANGAN INDUSTRI GULA AREN DALAM MENDUKUNG SWASEMBADA GULA NASIONAL
}

\author{
Ir. H. Dian Kusumanto \\ Presiden Aren Foundation \\ *Corresponding author : diankusumanto@yahoo.co.id
}

\begin{abstract}
This study aims to provide a critical and in-depth analysis of the Arenga palm sugar industry development opportunities in support of national self-sufficiency in sugar, as long as the self-sufficiency program in Indonesia only rely on cane-based sugar industry. Failure of sugar self-sufficiency efforts so far indicate that sugar cane-based industry is need for the development of alternatives to meet the national sugar needs. Efforts to increase sugarcane production is constrained by the difficulty of developing a planting area, declining soil fertility and productivity of sugarcane. Refiners are already very old age is also not able to be replaced with a new sugar plant that requires very large investments. This situation led to inefficiencies and yield of sugar cane harvest has declined. In addition, there are great opportunities Arenga plant which has many advantages compared to cane as raw material for sugar industry. However, the development of the sugar industry based Arenga requires government policies that encourage the availability of information, science and latest technology of Arenga, incentives for investors in the form of ease of licensing and the provision of land, concerns about the proliferation of liquor is also to be anticipated by the legislation, monitoring and enforcement. Alternative policy is believed will give great confidence in supporting national self-sufficiency in sugar, also confirmed to the welfare of its players. Then advised all parties to take on the role in order to meet Arenga presence as supporting sugar self-sufficiency in Indonesia.
\end{abstract}

Keywords: Palm sugar industry, self supporting sugar, sugarcane, national sugar policy, programme of sugar production.

\begin{abstract}
ABSTRAK
Penelitian ini bertujuan untuk memberikan analisis kritis dan mendalam tentang peluang pengembangan industri Arenga gula kelapa dalam mendukung nasional swasembada gula, selama program swasembada di Indonesia hanya mengandalkan industri gula berbasis tebu. Kegagalan upaya swasembada gula sejauh ini menunjukkan bahwa industri berbasis tebu butuhkan untuk pengembangan alternatif untuk memenuhi kebutuhan gula nasional. Upaya untuk meningkatkan produksi tebu terkendala oleh sulitnya mengembangkan area tanam, penurunan kesuburan tanah dan produktivitas tebu. Penyuling sudah berusia sangat tua juga tidak dapat digantikan dengan tanaman gula baru yang membutuhkan investasi yang sangat besar. Situasi ini menyebabkan inefisiensi dan hasil panen tebu telah menurun. Selain itu, ada yang besar kesempatan Arenga tanaman yang memiliki banyak keunggulan dibandingkan dengan tebu sebagai bahan baku untuk industri gula. Namun, pengembangan industri gula berbasis Arenga membutuhkan kebijakan pemerintah yang mendorong ketersediaan informasi, ilmu pengetahuan dan teknologi terbaru
\end{abstract}


dari Arenga, insentif bagi investor dalam bentuk kemudahan perizinan dan penyediaan lahan, kekhawatiran tentang proliferasi minuman keras juga harus diantisipasi oleh undang-undang, pengawasan dan penegakan hukum. kebijakan alternatif diyakini akan memberikan keyakinan besar dalam mendukung nasional swasembada gula, juga menegaskan untuk kesejahteraan pemainnya. Kemudian menyarankan semua pihak untuk mengambil peran dalam rangka memenuhi kehadiran Arenga sebagai penunjang swasembada gula di Indonesia

Kata kunci : Industri gula Aren, Swasembada gula, Gula Tebu, Kebijakan Pergulaan Nasional, Program Produksi Gula.

\section{PENDAHULUAN}

Pada tahun 2011 yang lalu Indonesia mengimpor gula sebesar 2,4 juta ton untuk memenuhi kebutuhan di dalam negeri. Padahal berbagai upaya sudah dilakukan agar angka impor gula itu tidak sebesar itu. Hal ini terjadi karena produksi gula dari bahan tebu pada kurun waktu dua dasa warsa terakhir terus mengalami penurunan, sementara kebutuhan konsumsi terus mengalami peningkatan dari tahun ke tahun mengikuti semakin bertambahnya jumlah penduduk dan kebutuhan industri makanan dan minuman. Produksi gula dalam negeri belum mampu memenuhi kebutuhan konsumsi gula, maka untuk memenuhi kebutuhan gula dilakukan impor gula dari luar negeri. Produksi gula rata-rata 2,26 juta ton per tahun, sementara konsumsi sekitar 5,10 juta ton per tahun. Defisit antara produksi dan kebutuhan konsumsi ini menyebabkan Indonesia harus mengimpor gula dari luar negeri. Angka impor gula juga mengalami peningkatan seiring dengan semakin besarnya defisit antara produksi dan konsumsi gula di dalam negeri.

Dalam hal ini kebijakan publik yang sudah ada adalah bahwa Industri Gula Nasional selama ini berbasis pada bahan baku dari tanaman tebu (Saccharum officinarum). Oleh karena itu segala hal menyangkut kebijakan public juga berbasis pada tebu, sehingga tanaman tebu sudah sangat mendominasi kebijakan tentang gula di Indonesia. Di sisi yang lain terdapat suatu komoditi yang bisa dijadikan bahan baku pembuatan gula, yaitu tanaman Aren. Aren memiliki banyak kelebihan dibandingkan tebu sebagai bahan baku gula. Pengembangan industri gula Aren adalah salah satu alternatif yang paling memiliki peluang dalam mengatasi hambatan-hambatan yang dialami oleh industri gula dari tebu. Alternatif kebijakan publik adalah tanaman Aren yang juga menghasilkan bahan baku yang bisa diolah menjadi gula. Dengan menggunakan teori-teori yang sudah ada ini alternatif kebijakan yang baru ini akan ditampilkan sebagai kebijakan pengganti dari kebijakan publik sebelumnya. Maka suatu saat nanti industri gula nasional kita tidak saja berbahan baku dari tanaman tebu tetapi juga dengan bahan baku dari tanaman Aren (Arenga pinnata).

Dari uraian di atas, maka penelitian ini akan berusaha menjawab permasalahan sebagai berikut : 
1. Bagaimana

$$
\text { peluang }
$$

pengembangan industri gula

Aren dalam mendukung swasembada gula secara nasional ?

2. Apa sajakah hambatanhambatan yang ada dalam pengembangan pengembangan industri gula Aren ?

3. Bagaimana cara atau strategi mengatasi hambatan-hambatan yang akan terjadi dalam pengembangan industri gula Aren tersebut?

\section{METODE PENELITIAN}

Jenis penelitian ini adalah deskriptif eksploratif, karena bertujuan menggali dan menemukan serta menggambarkan keadaan atau fenomena yang ada di lapangan. Design kualitatif yang dilakukan dengan case study/ historical study dan grounded study dilakukan dengan (i) melakukan analisis tentang sejarah gula dan Tebu dari masa ke masa, mengumpulkan kasus-kasus sehubungan dengan kebijakan gula dan tebu selama ini, kemudian mencari alasan yang menguatkan mengapa kebijakan alternatif diperlukan, (ii) melakukan analisis beberapa alternatif yang pernah diusulkan oleh publik dan mengujinya dalam interaksinya terhadap lingkungan dengan analisis SWOT, dan (iii) memilih alternatif kebijakan tersebut menjadi kebijakan baru dalam Swasembada Gula nasional.

$$
\text { Adapun tentang tema }
$$

swasembada gula instrumen teori yang digunakan adalah teori produksi dan teori tentang konsumsi. Sebab swasembada sendiri terdiri dari intrumen produksi dan intrumen konsumsi, swasembada akan terjadi jika besaran produksi yang ada adalah sama dengan atau lebih besar dibanding besaran konsumsi. Dengan kata lain, jika selisih antara angka produksi dikurangi angka konsumsi positif berarti swasembada tercapai.

\section{HASIL DAN PEMBAHASAN}

Industri pergulaan nasional saat ini menghadapi permasalahan yang kompleks. Indonesia yang pernah menjadi negara pengekspor gula terbesar kedua dunia sekitar tahun 1930 secara berangsur-angsur menurun menjadi negara importir gula, dan saat ini Indonesia telah menjadi importir terbesar pertama di Asia dan terbesar kedua dunia setelah Rusia. Masalah pokok dalam pergulaan nasional adalah rendahnya produksi akibat rendahnya produktivitas dan efisiensi industri gula nasional secara keseluruhan dimulai dari pertanaman tebu hingga pabrik gula. Semakin menurunnya luas areal dan produktivitas tebu yang dihasilkan petani serta rendahnya produktivitas pabrik gula serta manajemen pabrik gula yang tidak efisien adalah pemicu rendahnya produksi gula nasional. Ketergantungan pada impor, selain semakin menurunkan pertumbuhan industri gula dalam negeri, juga merupakan salah satu ancaman terhadap kemandirian pangan Indonesia dimana kebutuhan pangan 
pokok semaksimal mungkin dipenuhi oleh produksi dalam negeri.

\section{Swasembada Gula Berbasis Tebu}

Kebijakan swasembada gula nasional secara eksplisit baru dicanangkan pada tahun 2009 dan berakhir pada tahun 2014 dengan harapan tercapai sasaran yang dimaksudkan. Namun demikian sesungguhnya kebijakan tentang gula sudah sejak lama dilakukan, khususnya yang berhubungan dengan bahan baku gulanya yaitu tebu. Jadi kebijakan yang dicanangkan pada tahun 2009 itu sebenarnya adalah kebijakan yang sudah lama tentang pertebuan dan gula dengan tetap paradigma pembangunan gula yang berbasis tebu.

Industri gula tebu merupakan salah satu pilar dan penggerak ekonomi nasional. Soewandi (2004) mengatakan bahwa kebutuhan gula nasional Indonesia sebesar 3,2 juta ton per tahunnya sementara produksi dalam negeri sekitar 2 juta ton. Hal ini merupakan suatu kemunduran bagi bangsa Indonesia karena pada tahun 1975-1995, produksi gula nasional Indonesia bisa mencapai sekitar 2,5 juta ton. Menurunnya produksi gula tebu disebabkan oleh berbagai kelemahan yang hampir meliputi seluruh hirarki, diantaranya adalah pada level manajemen. Pada level ini, industri gula mengalami permasalahan mulai di tingkat perkebunan dan pabrik gula.

\section{Penurunan Luas Areal, Produktivitas dan Produksi Tebu}

Produksi gula dalam negeri secara umum mengalami penurunan. Penurunan terbesar terjadi pada tahun 1993-1999. Produksi gula paling rendah tercapai pada tahun 1999, yaitu sebesar 1,49 juta ton. Penurunan produksi gula dalam negeri tersebut antara lain disebabkan oleh penurunan areal dan peningkatan proporsi areal tebu tegalan, penurunan produktivitas lahan dan penurunan efisiensi di tingkat pabrik (Susilo dan Sinaga 2005).

Tabel 1. Perkembangan Luas Areal, Produksi dan Produktivitas Tebu dan Gula dari Tahun 1993 sampai 2007

\begin{tabular}{|c|c|c|c|c|c|c|}
\hline \multirow{2}{*}{ Tahun } & \multirow{2}{*}{$\begin{array}{c}\text { Luas } \\
\text { Areal } \\
\text { (ha) }\end{array}$} & \multicolumn{5}{|c|}{$\begin{array}{c}\text { Rendeme } \\
\mathbf{n}\end{array}$} \\
\hline & & (ton) & $\begin{array}{c}\text { (ton/ha } \\
\text { ) }\end{array}$ & $(\%)$ & (ton) & (ton/ha) \\
\hline & & & & & 2.482 .72 & \\
\hline 1993 & 420.687 & 37.593 .146 & 89,36 & 6,67 & $\begin{array}{r}5 \\
2.448 .83\end{array}$ & 5,9 \\
\hline 1994 & 428.726 & 30.545 .070 & 71,25 & 7,76 & $\begin{array}{r}3 \\
2.096 .47\end{array}$ & 5,71 \\
\hline 1995 & 420.630 & 30.096 .060 & 71,55 & 6,81 & $\begin{array}{r}1 \\
2.094 .19\end{array}$ & 4,98 \\
\hline 1996 & 403.266 & 28.603 .531 & 70,93 & 7,3 & 5 & 5,19 \\
\hline 1997 & 385.669 & 27.954 .441 & 72,48 & 7,93 & 2.189 .97 & 5,68 \\
\hline
\end{tabular}




\begin{tabular}{llllrrr}
\hline 1998 & 378.293 & 27.177 .766 & 71,84 & 5,53 & 3 & 3,94 \\
& & & & & 1.488 .95 & 9 \\
1999 & 340.800 & 21.401 .834 & 62,8 & 7,03 & 4,37 \\
& & & & & 1.690 .66 & 7 \\
2000 & 340.660 & 24.031 .355 & 70,54 & 7,19 & 7,96 \\
& & & & & 1.725 .46 & 7 \\
2001 & 344.441 & 25.186 .254 & 73,12 & 7,05 & 5,01 \\
& & & & & 1.755 .43 & \\
2002 & 350.723 & 25.533 .431 & 72,8 & 7,03 & 4 & 5,01 \\
& & & & & 1.631 .91 & \\
2003 & 335.725 & 22.631 .109 & 67,41 & 7,34 & 9 & 4,86 \\
& & & & & 2.051 .64 & 4 \\
2004 & 344.793 & 26.743 .180 & 77,56 & 7,88 & 5,95 \\
& & & & & 2.241 .74 & \\
2005 & 381.786 & 31.242 .267 & 81,83 & 7,35 & 2 & 5,87 \\
& & & & & 2.307 .02 & \\
2006 & 396.441 & 30.232 .833 & 76,26 & 7,78 & 7 & 5,82 \\
& & & & & 2.442 .76 & \\
2007 & 427.178 & 33.066 .042 & 77,41 & 7,65 & 1 & 5,72 \\
\hline
\end{tabular}

Sumber: Dewan Gula Indonesia (2008)

Luas areal tebu dan rendahnya rendemen gula nasional mempengaruhi penurunan produksi gula. Kondisi pabrik gula yang telah tua dan kesulitan tebang dan angkut telah mempengaruhi rendemen dan kualitas tebu sehingga biaya produksi gula lebih mahal. Rendahnya luas areal dan produktivitas tebu menyebabkan produksi tebu nasional juga semakin rendah. Penurunan produksi tebu nasional ini juga akibat dari penghapusan program TRI pada tahun 1999.

\section{Produktivitas Tebu Semakin Menurun}

Produktivitas Gula Hablur per hektar lahan tebu terus menurun dari dasa warsa ke dasawarsa hingga sekarang ini. Tahun 1920-an hingga 1940-an dianggap masa produktivitas gula tertinggi dalam sejarah gula Indonesia yaitu antara 15,1 - 17,6 ton/hektar. Pada tahun 1957 sampai 1975 saat awal nasionalisasi pabrik gula produktivitas gula turun pada kisaran 9,0-10,0 ton/hektar. Dengan pengembangan ke luar Jawa dan penanaman di lahan kering di era 1980-an sampai 1990-an produktivitas rata-rata nasional turun drastis pada kisaran 5,75 sampai 6,55 ton/hektar. Setelah itu hingga sekarang ini produktivitas rata-rata hanya pada kisaran angka 6,5 sampai 8,0 ton/hektar, meskipun sudah digelontor dengan berbagai macam program swasembada gula nasional (Dian Kusumanto, 2012). Tidak efisiennya pabrik-pabrik gula disebabkan karena mesin rata-rata berkapasitas kecil dan umur mesin sudah lebih dari 75 tahun. 
Selain itu, sistem manajemen yang lemah juga berakibat pada rendemen tebu ke gula rendah, biaya produksi per kg gula tinggi, dan produktivitas gula relatif rendah.

\section{Kebutuhan Konsumsi dan Impor Gula Terus Meningkat}

Impor juga dipengaruhi oleh peningkatan konsumsi gula. Ketika produksi terus mengalami penurunan, konsumsi domestik baik oleh rumah tangga maupu industri terus mengalami peningkatan. Peningkatan konsumsi terutama berkaitan dengan dua faktor yaitu pertambahan penduduk dan peningkatan pendapatan

Tabel 2. Produksi, Konsumsi dan Impor Gula

\begin{tabular}{cccc}
\hline Year & Production (ton) & Import (ton) & $\begin{array}{c}\text { Consumption } \\
\text { (ton) }\end{array}$ \\
\hline 1993 & 2.482 .724 & 236.719 & 2.337 .400 \\
1994 & 2.448 .833 & 128.399 & 2.941 .200 \\
1995 & 2.096 .471 & 523.988 & 3.343 .200 \\
1996 & 2.094 .195 & 975.830 & 3.069 .900 \\
1997 & 2.189 .974 & 1.364 .563 & 3.363 .300 \\
1998 & 1.791 .553 & 1.730 .473 & 3.300 .000 \\
1999 & 1.488 .599 & 2.187 .133 & 3.360 .000 \\
2000 & 1.690 .667 & 1.556 .700 & 3.300 .000 \\
2001 & 1.725 .467 & 1.500 .000 & 3.360 .000 \\
2002 & 1.755 .434 & 1.377 .854 & 3.300 .000 \\
2003 & 1.631 .919 & 1.571 .278 & 3.451 .000 \\
$2004 *)$ & 2.006 .575 & 791.861 & 2.460 .000 \\
\hline
\end{tabular}

Sumber : Badan Pusat Statistik dan DGI

*) Taksasi angka sementara

Terjadinya defisit produksi ini harus dipenuhi dari impor gula yang mencapai puncaknya sebesar 2,187 juta ton (1999) dan 2,4 juta ton (2011) atau $60-65 \%$ dari kebutuhan untuk konsumsi. Pada gambar 1 terlihat angka konsumsi cenderung naik secara atau pertumbuhan ekonomi. Konsumsi domestik baik oleh rumah tangga maupu indistri terus mengalami peningkatan.

Konsumsi gula per kapita selama tahun 1990-2000 yang semakin meningkat yaitu pada tahun 1990, 1995, 1996 dan 1997 berturut-turut adalah $13,38 \mathrm{~kg} ; 16,54 \mathrm{~kg} ; 15,76 \mathrm{~kg}$ dan $17,04 \mathrm{~kg}$ per kapita/tahun. Dengan semakin meningkatnya jumlah penduduk Indonesia, maka total kebutuhan konsumsi gula juga terus meningkat pada tahun 1993 konsumsi gula sebanyak 2,34 juta ton dan terus meningkat menjadi 3,45 juta ton pada tahun 2003 (Nainggolan K., $2005: 5$ ). 


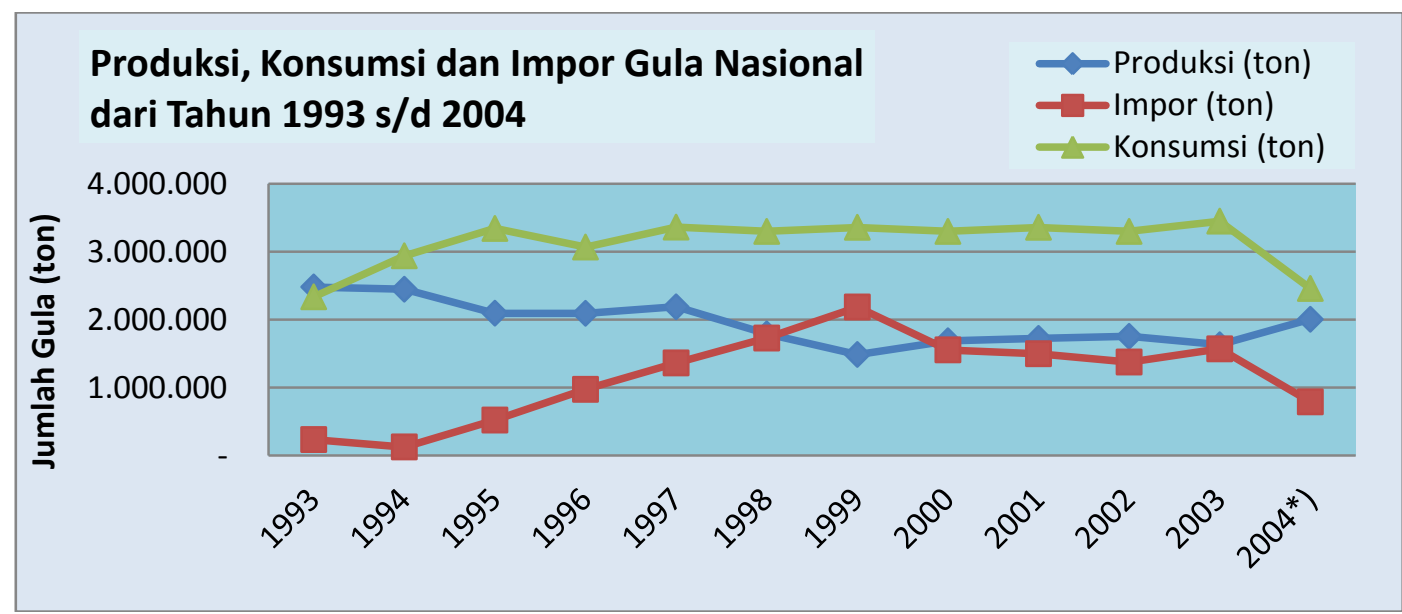

Gambar 1. Grafik Produksi, Konsumsi dan Impor Gula Nasional Tahun 19932004

\section{Kebijakan Pergulaan Nasional berbasis Tebu}

Harga gula di pasar internasional yang terus menurun dan mencapai titik terendah pada tahun 1999 juga menjadi penyebab kemunduran industri gula Indonesia. Penurunan harga gula ini terutama disebabkan oleh kebijakan hampir semua negara produsen utama dan konsumen utama melakukan intervensi yang kuat terhadap industri dan perdagangan gula. Sebagai contoh, hampir semua negara menerapkan tarif impor lebih dari 50\%. Di samping itu, kebijakan dukungan harga (price support) dan subsidi ekspor masih dilakukan oleh negara besar seperti Eropa Barat dan Amerika. Hal ini menempatkan pasar gula merupakan pasar dengan tingkat distorsi tertinggi kedua setelah beras (Noble, 1997; Kennedy, 2001;
Groombridge, 2001 dalam Susilo dan Sinaga, 2005).

Sebagai suatu komoditi yang strategis, pemerintah telah menerapkan berbagai kebijakan yang memiliki efek langsung ataupun tidak langsung terhadap pasang-surut terhadap industri gula nasional (Tabel 3). Kebijakan tersebut pada gilirannya mempengaruhi kinerja impor gula nasional. Kebijakan pemerintah tersebut mempunyai dimensi yang cukup luas, dari kebijakan input dan produksi, distribusi, dan kebijakan harga. Kebijakan pergulaan secara garis besar dapat dibagi menjadi 3 rezim yaitu (i) periode stabilisasi (1971-1996); (ii) perdagangan bebas/liberalisasi (1997-2001); dan (iii) pengendalian impor (2002sekarang). 


\section{Upaya Pengembangan Industri Gula Non Tebu}

Upaya-upaya untuk menggali potensi dan memanfaatkan pemanis alami non tebu telah dilakukan sejak lama terutama oleh masyarakat. Pengolahan gula merah dan gula cair dari aren, kelapa, lontar, nipah dan tanaman lainnya telah berlangsung puluhan tahun dan mungkin berabad lamanya seperti di Papua, Maluku dan Sulawesi Utara, demikian pula dengan pengolahan gula lontar di Nusa Tenggara Timur. Kelapa, aren dan lontar adalah tanaman-tanaman yang sangat potensial penghasil gula merah dan gula cair dari segi areal tanaman, pengolah yang terlibat, dan teknologi pengolahan yang tersedia. Oleh karena itu, potensi tanaman-tanaman ini sebagai alternative penghasil gula pasir, teknologi pengolahan gula pasir dari nira yang dihasilkan tanamantanaman ini serta kelayakan sebagai sumber gula alternative perlu diungkapkan untuk memaksimalkan pemanfaatannya (Rumokoi, 2004).

Urgensi tentang peluang perkebunan dan industri gula berbasis non Tebu dalam mendukung swasembada gula nasional, terpicu dari revitalisasi yang masih belum mencapai tujuannya. Maka menginventarisir kembali alternative kebijakan publik yang mungkin lebih efektif dalam mengatasi masalah Swasembada gula nasional dengan mempertimbangkan alternative kebijakan yang lebih efisien waktu dan anggaran serta lebih efektif dalam rangka pemenuhan konsumsi gula nasional masa depan (Dian Kusumanto, 2012).

Upaya pengembangan industri gula non tebu dari tanaman bit gula bisa dipertimbangkan. Potensi Bit sebagai bahan baku gula alternatif sangat besar, karena Bit memiliki keunggulan antara lain kebutuhan air yang lebih rendah yakni sepertiga dari tebu, mudah tumbuh di tempat marjinal, dan nilai rendemen (kandungan gula) yang lebih tinggi dibandingkan tebu. Pada tahun 2010 Pusat Penelitian Perkebunan Gula Indonesia (P3GI) bekerjasama dengan PT. Gula Bit Nusantara (GBN) dan Direktorat Jenderal Perkebunan Kementerian Pertanian mulai mengembangkan budidaya gula bit tropika (Anonimous, 2010). Tanaman bit gula (Beta vulgaris L) yang memiliki potensi produktivitas cukup tinggi mencapai 80 ton per hektar dengan masa tanam hanya 6-8 bulan serta rendemen minimal 10 persen (Anonimous, 2010).

Upaya pengembangan industri gula non tebu dari tanaman Sorgum juga bisa menjadi alternatif lain. Sorgum adalah tanaman serealia yang batangnya bisa menghasilkan nira yang diolah menjadi gula dan biomas untuk jadi pakan ternak. Tanaman Sorgum juga bisa menghasilkan bulirbulir biji hingga 4-5 ton per hektare untuk tepung yang berkadar gula tinggi. Biomas yang bisa dipanen sebanyak 30 ton hektar dan akan menghasilkan nira sebanyak 4.000 liter (Anonimous, 2012). Keunggulan Sorgum jika dibandingkan dengan tebu dari sisi umur tanaman saat dipanen yang lebih pendek, biaya budidaya lebih murah, serta cocok untuk ditanam di daerah kering. Sorgum sudah bisa dipanen dalam 100 hari sampai 120 hari, biaya budidayanya sekitar sepertiga dari biaya budidaya tebu. 
Penyediaan Bahan Baku Industri Gula Nasional

Peluang pengembangan Aren sebagai kebijakan alternatif bahan baku industri gula adalah sangat besar karena banyaknya keunggulan Aren dibanding Tebu dalam sistem industri gula. Kebijakan swasembada gula dengan pengembangan industri gula berbasis Aren merupakan kebijakan sebelum kebijakan (ex ante, pre-hoc, anticipatory, atau prospective policy). Analisis peluang keunggulan Aren dibanding Tebu yang mendukungnya sebagai kebijakan alternatif dapat ditinjau dari beberapa aspek yang terkait, yaitu : aspek produksi, aspek ekonomi dan kesejahteraan petani, aspek lahan dan lingkungan, aspek pengolahan dan investasi pabrik, aspek sosial budaya dan politik gula, maupun dari aspek politik ekonomi gula dunia.

Keunggulan Aren dari aspek produksi, ekonomi dan kesejahteraan petani, karena Aren bisa menghasilkan Nira bahan gula sepanjang tahun, dalam setiap hektar perkebunan ditanam 200 pohon Aren yang berpotensi menghasilkan 1.500 liter/ha/hari. Nira Aren bisa diolah menjadi gula kristal putih layaknya gula tebu dan setiap hektarnya Aren bisa menghasilkan gula sampai 70 ton per/tahun/ha. (Dian Kusumanto, 2012). Perkebunan Aren memerlukan tenaga kerja cukup banyak, dan dinamika pekerjaannya sangat padat sehingga akan menghidupkan ekonomi masyarakat setempat. Keunggulan lainnya, usaha tani Aren bisa dikombinasi dengan usaha yang lain di dalam areal yang sama secara terpadu dan juga masih menghasilkan kolangkaling, ijuk, lidi, sagu, kayu dan lainlain.

Produktivitas tebu yang semakin lama semakin menurun, terakhir hasil gulanya dari se hektar lahan tebu hanya sebesar antara 5-7 ton/ha/tahun. Sangat jauh dengan produktivitas kebun Aren yang mampu menghasilkan 50-100 ton. Itu artinya bahwa Aren mempunyai kemampuan 10 kali lipat lebih dari Tebu (Dian Kusumanto, 2012 : 2). Perkebunan Aren itu bisa dibangun di lahan yang selama ini kurang produktif atau di lahan kering yang berbukit-bukit. Sedangkan tebu selalu bersaing dengan lahan-lahan sawah produktif, dan lahan untuk pangan lainnya. Jika Aren dikembangkan untuk Food Estate sebagai penghasil gula, maka Aren akan dapat mendukung bahkan menggantikan tebu, maka akan banyak kontribusi pangan yang bisa diberikan (Dian Kusumanto, 2012 : 2).

Keunggulan Aren dari aspek lahan dan lingkungan, karena lahan yang dibutuhkan perkebunan dan industri gula Aren lebih fleksibel dan mudah dibandingkan dengan penyediaan lahan untuk perkebunan tebu. Pengembangan Aren juga memberikan sinergi yang positif pada terjaganya lingkungan dari degradasi saat dibangunnya perkebunan. Luasan areal lahan yang diperlukan lebih sedikit (sepersepuluhnya) kita sudah dapat memenuhi swasembada gula nasional. Selain itu Aren bisa memanfaatkan lahan yang miring 
sampai curam, sehingga bisa mencegah kelongsoran dan tidak bersaing dengan lahan tanaman pangan. Populasi pohon Aren juga bisa menimbulkan sumber air baru, serta memiliki Carbon sequestration cukup tinggi akan meningkatkan nilai lingkungan dalam Carbon Trading dan isu tentang Global Warming.

Tabel 4. Perbandingan Proyeksi Kondisi dan Hasil Industri Gula berbasis Tebu dan Berbasis Aren

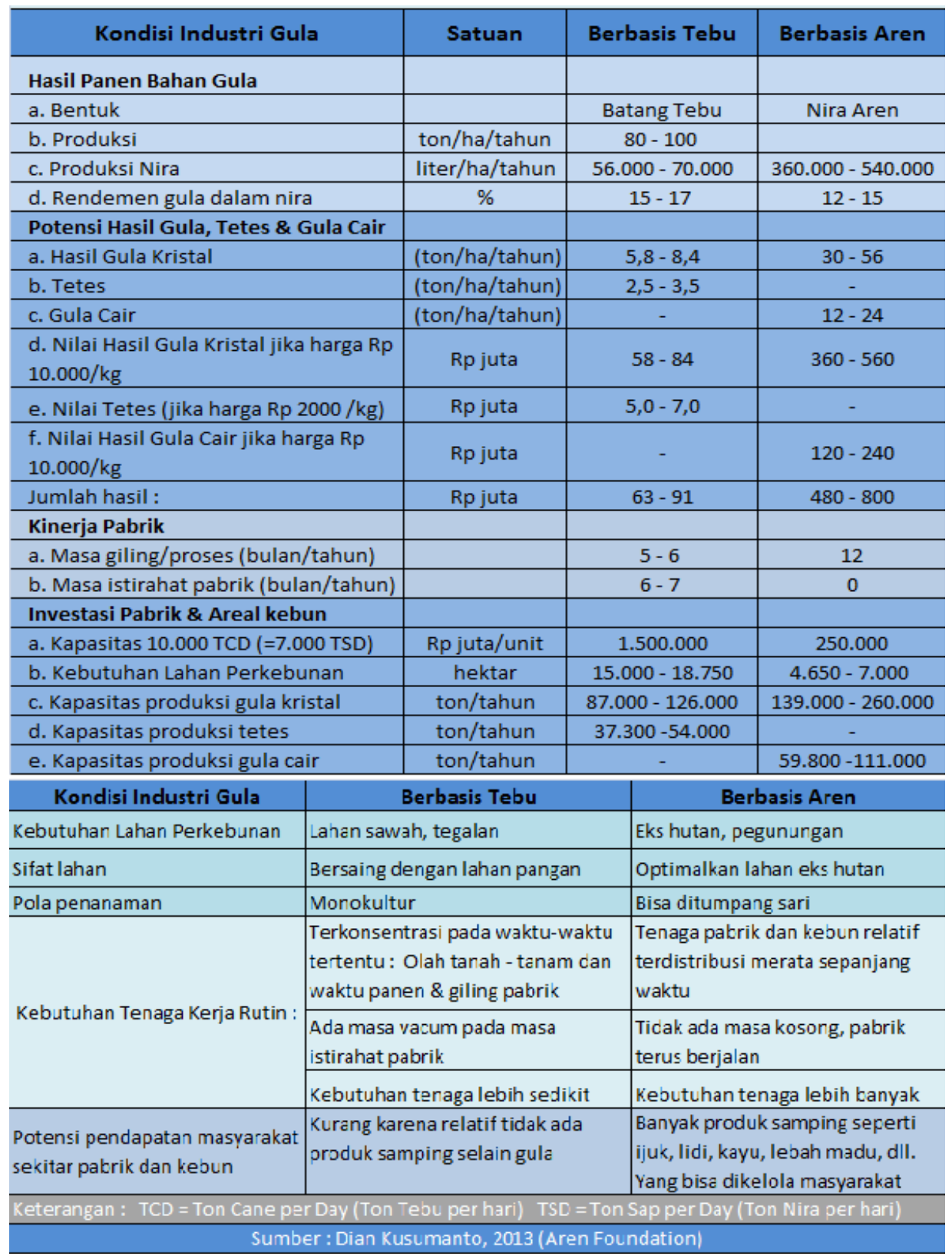

Sumber : Dian Kusumanto (2012)

Aren dari aspek pengolahan dan investasi pabrik lebih unggul dibanding tebu, karena produk yang dipanen langsung berbentuk nira cair sehingga proses untuk menjadi gula bisa lebih cepat, tidak memerlukan 
peralatan dan proses yang rumit seperti pada pabrik gula berbasis tebu. Dengan demikian investasi mesin dan peralatan pabrik menjadi relatif lebih murah dan lebih sederhana, kebutuhan lahan untuk lokasi pabrik juga lebih sedikit. Keunggulan yang lebih lainnya, karena pabrik bisa beroperasi sepanjang tahun, sehingga lebih efisien.

Keunggulan Aren dari aspek sosial budaya dan politik ekonomi gula nasional dan dunia, karena budaya mengkonsumsi gula masyarakat selama ini berbentuk gula kristal putih dan Aren juga bisa diolah menjadi gula bentuk kristal putih. Gula aren juga merupakan salah satu pemanis yang telah diproduksi oleh bangsa Indonesia sejak dahulu kala yang berkhasiat dan fungsi bagi kesehatan dan aneka pengolahan pangan dan obat. Trend konsumsi gula yang akan datang, mengarah pada konsumsi pangan yang menggunakan prinsip-prinsip organik. Dengan demikian Aren akan lebih tahan terhadap terjadinya perubahan trend konsumsi gula dan perdagangan gula dunia yang distorsif.

Jika isu-isu lingkungan global akan dijadikan alat persaingan ekonomi dunia, makan Aren diprediksi aman menghadapinya, karena Aren dikenal sebagai tanaman yang sangat pro terhadap lingkungan. Politik gula berbasis tebu terlalu rumit, penuh dengan kepentingan namun memerlukan biaya besar dan waktu panjang menuju swasembada. Aren punya peluang lebih besar karena produktivitasnya yang jauh lebih besar, investasi yang lebih murah serta efek kebijakan lebih aman dari kompetisi pasar. Masing-masing negara tentu akan berusaha melindungi rakyatnya sebagai produsen maupun sebagai konsumen gula dan industri di dalam negerinya.

\section{Hambatan \\ Pengembangan Industri Berosis Aren Dalam Perumusan dan Implementasinya}

Dalam pemetaan hambatan kebijakan industri gula berbasis Aren, untuk mengidentifikasinya adalah dengan menyusun pohon hambatan (constrain tree). Menurut Nugraha MQ. (2005 : 11.25), pohon hambatan merupakan tampilan grafis tentang keterbatasan dan hambatan yang menghalangi pencapaian tujuan. Pohon hambatan menyisipkan hambatan-hambatan ke dalam pohon sasaran seperti gambar berikut :

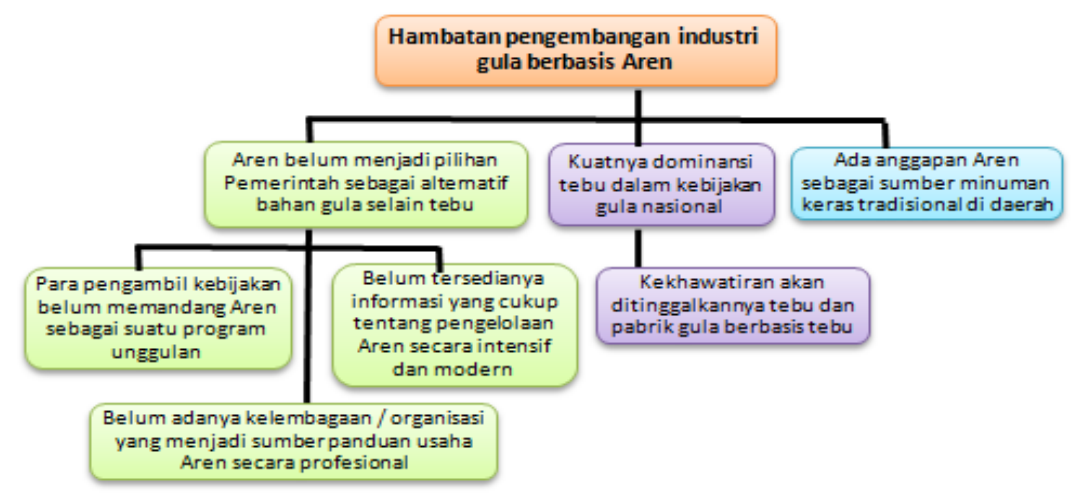

Gambar 2. Skema pohon hambatan (constrain tree) pengembangan industri gula berbasis Aren 


\section{Kuatnya dominansi tebu} dalam kebijakan gula nasional itu terjadi karena memang belum ada kebijakan yang dalam waktu dekat mampu menggantikan tebu sebagai bahan baku utama gula. Oleh karena itu untuk menggantikan dominasi tidak bisa dilakukan secara revolutif (serta merta), namun harus dilakukan secara evolutif (secara bertahap). Kebijakan alternatifnya harus dipersiapkan dengan sangat matang dan dilakukan secara masif dan terstruktur. Artinya, kebijakan swasembada berbasis tebu tetap harus dilakukan secara rasional dan proporsional, agar energi nasional tidak terkuras habis tersedot untuk kebijakan yang secara long term (jangka panjang) dipastikan kurang efektif. Azas efisiensi dan efektifitas dalam menetapkan strategi bertahan (defensif) dengan memilih kebijakan dan program yang investasinya tidak terlalu besar namun efektif. Kebijakan dan program yang bisa dihindari adalah kebijakan yang bersifat ofensif atau ekspansif, karena besarnya hambatan (threat) dan kecilnya peluang (opportunity). Hambatan akan semakin besar jika tidak didukung dengan kekuatan (strength) yang ada di lingkungan internal. Hambatan juga menjadi besar dan sulit diatasi manakala kelemahan (weakness) juga belum bisa diatasi dengan baik.

Dalam kebijakan swasembada gula berbasis pada tanaman tebu dari hasil analisis SWOT dan penilaian kekuatannya adalah tergambar sebagaimana skema berikut ini :

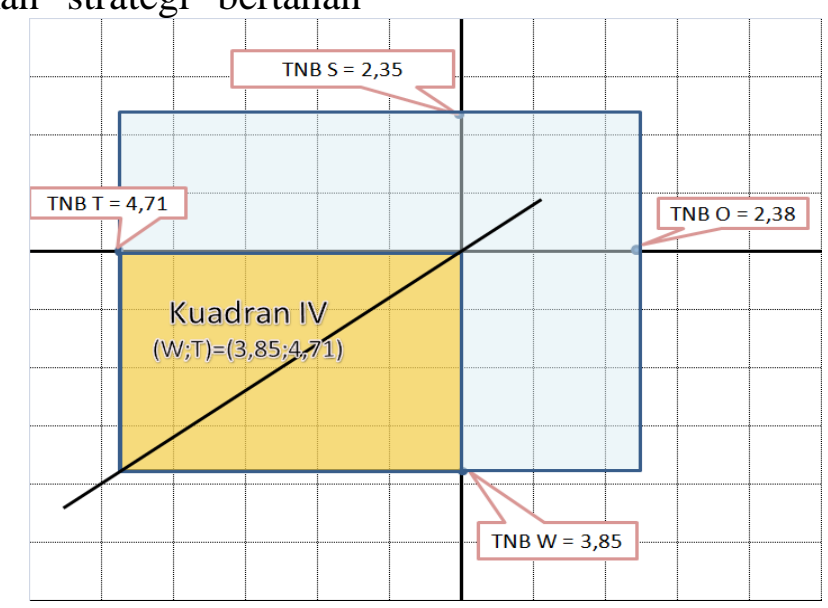

\section{Gambar 3. Peta Posisi Kekuatan Kebijakan Swasembada Gula berbasis Tebu pada Kuadran IV}

$\begin{array}{lll}\text { Pemilihan tingkat urgensi } & \text { kemiskinan, (ii) dapat meningkatkan } \\ \text { alternatif strategi yang dipilih } & \text { kesejahteraan masyarakat, (iii) } \\ \text { mendapat dukungan SDM, biaya dan } \\ \text { dilakukan dengan mempertimbangkan } \\ \text { beberapa kriteria yang menjadi }\end{array}$


(weakness) sebagai suatu faktor lingkungan internal. Karena itu strategi kebijakannya adalah mengatasi kelemahan (weakness) dengan menggunakan kekuatan (strength) yang ada. Maka upayanya adalah (i) meningkatkan produktivitas lahan, (ii) meningkatkan rendemen dan mutu gula, (iii) melakukan efisiensi dan rasionalisasi SDM, (iv) melakukan deversifikasi usaha yang kreatif yang mengarah pada minimalisasi input dan memaksimalisasi output, dan (v) melakukan pembenahan manajemen sehingga bisa memaksimalkan SDM, sarana prasarana dan aset yang sudah dimiliki.

Dengan demikian jika Strategi

bertahan (defensif) dipilih, maka yang dilakukan adalah upaya pengembangan perkebunan Aren secara bertahap sebagai basis pendukung di masa yang akan datang. Areal Aren dipersiapkan pada lahanlahan tebu yang dianggap kurang produktif, misalnya pada lahan-lahan kering yang ada di Pulau Jawa maupun di luar Jawa. Sistem tumpang sari juga bisa dipilih, sebab Aren memungkinkan untuk ditanam di sela-sela perkebunan tebu. Pengembangan alternatif bahan baku selain tebu tidak dilakukan secara revolutif tetapi secara evolutif yang dilakukan secara bertahap dan terencana, sambil mengatasi hambatan-hambatan dan kemungkinan buruk yang mungkin akan terjadi.

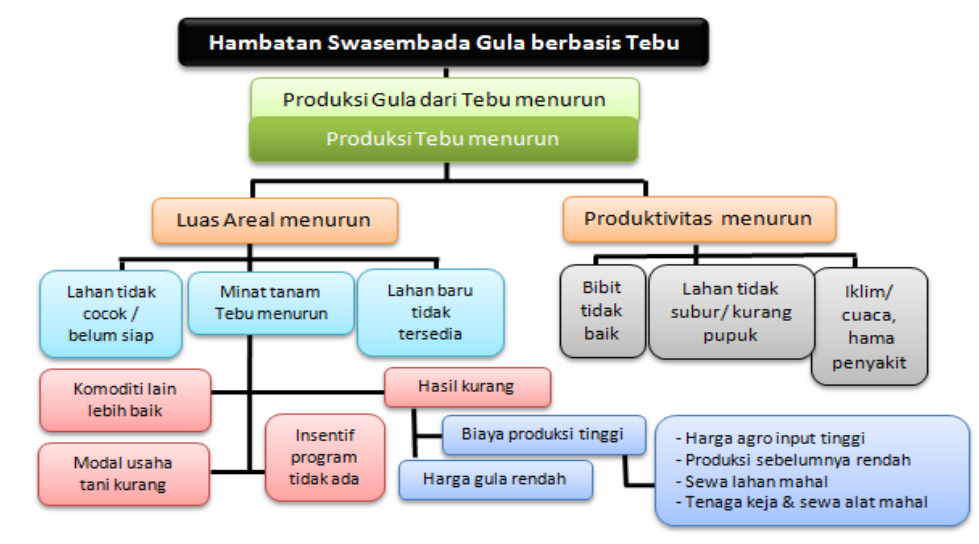

Gambar 4. Skema pohon hambatan swasembada gula berbasis tebu dari sisi produksi bahan baku tebu

Upaya swasembada gula dengan mengandalkan bahan baku dari tebu menemui minimal dua hambatan utama, yaitu luas areal tanam tebu dan produktivitas lahan tebu yang semakin merosot. Penambahan areal tanam tebu memang menjadi prasyarat utama untuk meningkatkan produksi tebu, namun upaya ini terhambat banyak hal seperti : (i) ketidaksesuaian lahan; (ii) lahan tidak cukup tersedia; dan (iii) minat menanam tebu yang semakin menurun. Hasil usaha tani tebu kurang karena harga gula yang rendah di tingkat petani produsen, biaya-biaya produksi tinggi yang disebabkan harga-harga agro input naik, ongkos tenaga kerja dan sewa alat mesin pertanian semakin naik, dan produksi sebelumnya rendah sehingga modal tidak mencukupi.

Hambatan swa sembada gula berbasis Aren karena Aren belum menjadi pilihan Pemerintah sebagai alternatif bahan gula selain tebu. 
Pemerintah selama ini belum secara serius mencari alternatif bahan baku gula selain tebu. Seandainya ada upaya-upaya pencarian alternatif bahan baku selain tebu, ternyata Aren belum pernah menjadi alternatif yang dipilih. Beberapa hal yang diduga menjadi sebab mengapa Aren belum menjadi alternatif yang eksplorasi secara sungguh-sungguh adalah (i) para pengambil kebijakan belum memandang Aren sebagai suatu program unggulan; (ii) belum tersedianya informasi yang cukup tentang pengelolaan Aren secara intensif dan modern; dam (iii) belum adanya kelembagaan atau organisasi yang menjadi sumber panduan usaha Aren secara profesional.

\section{Hambatan atas kekhawatiran} penyalahgunaan nira Aren untuk minuman keras. Selama ini memang nira aren sering dimanfaatkan tidak saja diolah menjadi gula, tetapi juga menjadi minuman fermentasi yang mengandung alkohol, seperti tuwak, balok, saguer, bandrek, 'cap tikus', ciu, arak dan lain-lain di berbagai daerah secara tradisional oleh masyarakat. Dengan pengembangan Aren maka dikhawatirkan akan semakin marak juga produksi minuman keras sehingga ada keengganan pemerintah untuk menganjurkan menanam Aren. Langkah-langkah persuasif, antisipatif dan prefentif seperti melakukan pengawasan yang lebih ketat dengan payung hukum yang implementatif dan penerbitan Perda khusus dalam pengembangan Aren yang aman. Upaya prefentif misalnya registrasi petani, para penyadap Nira Aren, dan pabrik pengolah gula Aren. Upaya represif dengan penegakan hukum dan peraturan akan mengurangi kekhawatiran di atas.

Hambatan karena kurangnya informasi (IPTEK) dan hasil-hasil penelitian tentang Aren. Kurangnya informasi dan hasil-hasil penelitian tentang Aren ini merupakan hambatan dalam pengembangan Aren ke depan. Selama ini rujukan berupa buku-buku referensi juga masih sangat kurang, terutama yang menyangkut standar operasional prosedur (SOP), GAP atau Good Agriculture Practise dan GPP (Good Processing Practise) dalam pembangunan perkebunan maupun untuk mendirikan pabrik gula berbasis Aren yang maju dan modern. Demikian juga panduan yang menyangkut penjaminan mutu produk gula dalam membangun industri gula Aren yang maju dan modern. Untuk meretas hambatan ini perlu (i) ada suatu lembaga yang secara intensif mengup-date informasi, teknologi dan hasil-hasil penelitian yang ada serta mengekspos secara luas ke publik; (ii) kebijakan untuk mengaktifkan lembaga resmi yang ada (seperti Balit Palma di Manado, P3GI di Pasuruan) guna meneliti dan mengembangkan IPTEK tentang Aren; (iii) kebijakan yang menjadikan Aren menjadi program swasembada gula nasional; (iv) kebijakan yang memungkinkan seluruh lembaga yang ada bisa bekerja sama, menjalinkan visi dan misi dalam bentuk lembaga organisasi dan forumforum pertemuan ilmiah, teknis, profesi maupun bisnis dengan lingkup Aren.

\section{Strategi Pengembangan Industri Gula Berbasis Aren Untuk Menjadi Suatu Kebijakan Baru Dalam Upaya Swasembada Gula Nasional}

Untuk mengetahui strategi dalam pengembangan industri gula berbasis Aren, maka perlu dianalisis lingkungan internal berupa kekuatankekuatan (strengths) dan kelemahankelemahan (weakness) dan eksternal berupa peluang-peluang 
(opportunities) dan hambatan- SWOT berikut. hambatan (treaths) dengan metode

Tabel 5. Matriks Analisis Lingkungan Internal dan Eksternal pada Pengembangan Industri Gula Berbasisi Aren dalam mendukung swasembada gula nasonal

\begin{tabular}{|c|c|}
\hline \multicolumn{2}{|c|}{ Analisis lingkungan Internal : } \\
\hline Kekuatan (Strength) : S & Kelemahan (Weakness) : W \\
\hline $\begin{array}{l}\text { Aren mempunyai produk yang beraneka } \\
\text { macam dan sangat bermanfaat \& bernilai } \\
\text { cukup tinggi }\end{array}$ & $\begin{array}{l}\text { Aren belum menjadi program } \\
\text { pemerintah }\end{array}$ \\
\hline $\begin{array}{l}\text { Aren mempunyai produktivitas yang } \\
\text { tinggi dalam menghasilkan bahan gula } \\
\text { (nira) }\end{array}$ & $\begin{array}{l}\text { Aren masih dikelola secara tradisional } \\
\text { dan apa adanya }\end{array}$ \\
\hline $\begin{array}{l}\text { Aren mudah diolah menjadi gula kristal } \\
\text { dan gula lainnya }\end{array}$ & $\begin{array}{l}\text { Informasi Teknologi, Referensi dan } \\
\text { penelitian Aren masih sangat minim }\end{array}$ \\
\hline $\begin{array}{l}\text { Sudah ditemukan beberapa teknologi } \\
\text { pengembangan Aren di beberapa tempat }\end{array}$ & $\begin{array}{l}\text { Umur mulai berproduksi Aren dianggap } \\
\text { terlalu lama } 7 \text { (tujuh) tahun }\end{array}$ \\
\hline $\begin{array}{l}\text { Dengan usaha skala kecil Aren sudah } \\
\text { mampu mencukupi pendapatan petani }\end{array}$ & $\begin{array}{l}\text { Pengelolaan kebun Aren secara } \\
\text { tradisional dianggap berat dan } \\
\text { memerlukan tenaga bahan bakar yang } \\
\text { banyak }\end{array}$ \\
\hline \multicolumn{2}{|c|}{ Analisa lingkungan Eksternal : } \\
\hline Peluang (Opportunity) : O & Hambatan/Ancaman (Threat) : T \\
\hline $\begin{array}{l}\text { Kebutuhan konsumsi gula nasional } \\
\text { sangat besar karena revitalisasi industri } \\
\text { gula berbasis Tebu tidak berhasil }\end{array}$ & $\begin{array}{l}\text { Ada anggapan Aren sebagai sumber } \\
\text { minuman keras tradisional di daerah }\end{array}$ \\
\hline $\begin{array}{l}\text { Kebutuhan konsusi gula yang sehat } \\
\text { karena kesadaran tentang makanan yang } \\
\text { aman dan organic dengan pasar yang luas }\end{array}$ & $\begin{array}{l}\text { Belum adanya kelembagaan / organi- } \\
\text { sasi yang menjadi sumber panduan } \\
\text { usaha Aren secara profesional }\end{array}$ \\
\hline $\begin{array}{l}\text { Aren dengan teknologi terbaru bisa } \\
\text { diolah menjadi gula yang diperlukan } \\
\text { konsumen sudah dilakukan terhadap } \\
\text { komoditi lain di tempat lain }\end{array}$ & $\begin{array}{l}\text { Para pengambil kebijakan belum } \\
\text { memandang Aren sebagai suatu } \\
\text { program unggulan }\end{array}$ \\
\hline $\begin{array}{l}\text { Produk Gula Aren dikenal memiliki nilai } \\
\text { lebih karena khasiat yang lebih } \\
\text { menyehatkan dan dikelola secara organic }\end{array}$ & $\begin{array}{l}\text { Belum tersedianya informasi yang } \\
\text { cukup tentang pengelolaan Aren secara } \\
\text { intensif dan modern }\end{array}$ \\
\hline $\begin{array}{l}\text { Ketersediaan lahan untuk pengembangan } \\
\text { Aren masih sangat melimpah (di luar } \\
\text { Jawa) }\end{array}$ & $\begin{array}{l}\text { Pemerintah memilih komoditi lain } \\
\text { sebagai alternatif bahan gula selain tebu } \\
\text { (bit gula, dll.) dan bukan Aren }\end{array}$ \\
\hline $\begin{array}{l}\text { Analisis } \\
\text { dilakukan dengan penyusunan tabel } \\
\text { Evaluasi Faktor Internal Dan Eksternal } \\
\text { (Lampiran 1), dan penilaian dan } \\
\text { penentuan tujuan atau strategi }\end{array}$ & $\begin{array}{l}\text { (Lampiran 2) dan pemilihan strateg } \\
\text { pengembangan industri gula Arer } \\
\text { mendukung swasembada gula nasiona } \\
\text { dengan teknik tapisan tersaji dibawal } \\
\text { ini (tabel 6). }\end{array}$ \\
\hline
\end{tabular}


Tabel 6. Pemilihan Strategi Pengembangan Industri Gula Aren Mendukung Seasembada Gula Nasional dengan Teknik Tapisan

\begin{tabular}{clccccc}
\hline No. & \multicolumn{1}{c}{ Alternatif Strategi } & Efektif & Kemudaha & Biaya & Total & Ket \\
\hline 1. $\begin{array}{l}\text { Pengembangan Industri Gula Aren } \\
\text { Kristal untuk swasembada gula } \\
\text { nasional pengganti tebu }\end{array}$ & 5 & 4 & 4 & 13 & I \\
2. $\begin{array}{l}\text { Pengembangan Gula Aren Organik } \\
\text { yang Sehat berdaya saing tinggi }\end{array}$ & 3 & 5 & 4 & 12 & II \\
\hline
\end{tabular}

Skema peta kekuatan dukungannya dalam misi mendukung berdasarkan hasil penilaian terhadap swasembada gula, serta tingkat bobot masing-masing faktor keterkaitan antara faktor lingkungan lingkungan yang ada, tingkat urgensi satu dengan lainnya terletak di atau kepentingannya, tingkat kekuatan kuadran I.

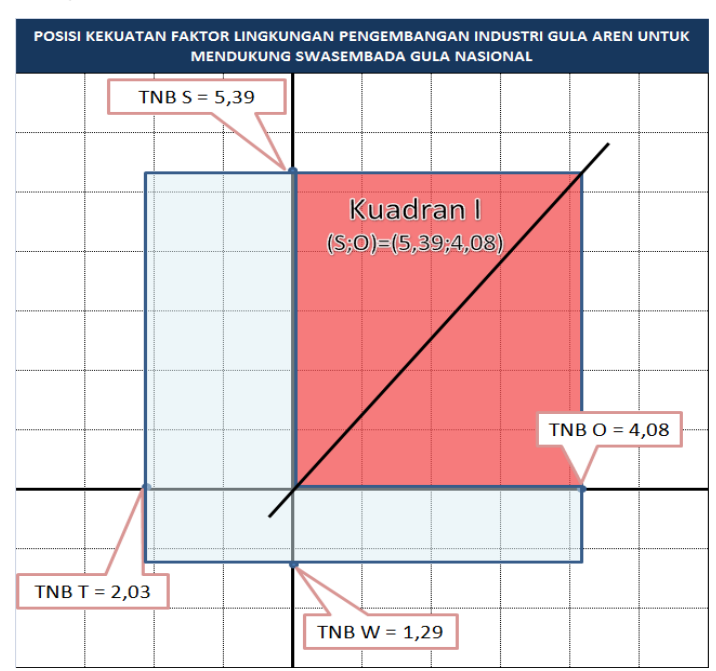

Gambar 5. Posisi Kekuatan Faktor Lingkungan Pengembangan Industri Gula Aren untuk Mendukung Swasembada Gula Nasional

Dengan posisi peta kekuatan ada pada kuadran I, maka strategi yang dilakukan adalah strategi ofensif atau ekspansif (offensive and expansive strategy) atau sebagai strategi pengembangan, pertumbuhan, perluasan. Dimana dalam mencapai tujuan pengembangan swasembada gula berbasis Aren atas peluangpeluang (opportunities) yang ada dengan segenap kekuatan (strengths). Disisi lain hambatan (treaths) dan kelemahan (weaknesses) yang ada harus diatasi terlebih dahulu. Dengan posisi seperti ini maka kebijakan pengembangan perkebunan dan industri gula Aren dalam mendukung swasembada gula nasional dianggap memiliki keunggulan kompetitif. Maka strategi yang dipilih untuk mengembangkan industri gula berbasis Aren ini, yaitu (i) melakukan pengembangan informasi tentang Aren secara lebih luas; (ii) 
menjadikan pengembangan Aren sebagai kebijakan nasional; (iii) memberikan insentif dan kemudahan kepada lembaga yang mengembangkan dan berinvestasi Aren.

Strategi yang dilakukan untuk pengembangan informasi tentang Aren ini perlu adanya suatu lembaga yang dengan intensif, secara terus menerus mengup-date informasi, teknologi dan hasil-hasil penelitian yang ada, membentuk forum semacam Dewan Aren Nasional, Asosiasi Aren Nasional, Pusat Riset Aren dan lainlain. Lembaga resmi yang ada seperti Balit Palma di Manado, P3GI di Pasuruan, dan lain-lain dalam meneliti dan menyebarkan informasi, ilmu dan teknologi tentang Aren dan pengembangannya.

Strategi menjadikan pengembangan Aren sebagai kebijakan nasional ini adalah suatu keharusan (ofensif) yang dilakukan untuk menolong (mendukung) swasembada gula secara jangka panjang. Ada 2 (dua) tujuan atau strategi utama yang terpilih, pertama dengan pengembangan industri gula Aren kristal untuk swasembada gula nasional pengganti tebu, dan kedua dengan pengembangan gula Aren organik yang sehat berdaya saing tinggi.

Faktor-faktor utama untuk membangun swasembada gula itu terdiri dari peningkatan produksi gula dan penurunan konsumsi gula. Upaya peningkatan produksi gula selama ini menjadi faktor kelemahan internal dalam berswasembada gula.
Sedangkan konsumsi gula sebenarnya akan menjadi peluang pasar bagi industri gula itu sendiri, untuk mengurangi konsumsi dilakukan dengan diversivikasi dan penurunan konsumsi gula per kapita. Jika faktorfaktor produksi yang harus mendapat perhatian lebih banyak, maka upaya dan kebijakan yang diambil harus mengarah pada meningkatkan luas areal tebu, meningkatkan produktivitas tebu, meningkatkan mutu tebu, dan meningkatkan efisiensi pabrik gula. Namun demikian seperti di pembahasan terdahulu, yang dianjurkan untuk dihindari adalah upaya meningkatkan luas areal secara ekspansif, karena retensi (penolakan) terhadap upaya ini sangat besar. Jika ini sulit dilakukan, maka pola pikir swasembada gula adalah dengan memberi peluang bahan baku non tebu untuk mengambil peran.

Dalam membangun swasembada gula, maka upaya pokok yang dilakukan adalah meningkatkan produksi gula dan sekaligus mengurangi konsumsi gula. Untuk mengurangi konsumsi gula maka langkah upayanya adalah mengurangi jumlah konsumen dan mengurangi jumlah konsumsi gula per kapita. Namun ini tidak menjadi perhatian dalam kebijakan swasembada gula, karena konsumsi dikehendaki dalam hidupnya perdagangan untuk penyerapan pasar gula.

Upaya pokok yang menjadi dominan selama ini adalah produksi gula yang bertumpu hanya dari bahan baku tebu. Maka ada beberapa 
langkah solusi dalam mendukung swasembada gula, yaitu memproduksi gula dengan bahan baku tidak hanya tebu, karena faktor-faktor pendukung swasembada gula berbasis tebu selalu gagal mencapai sasarannya. Kegagalan meningkatkan luas areal, kegagalan meningkatkan produktivitas dan mutu tebu, serta kegagalan meningkatkan efisiensi pabrik gula. Maka ditengah sulitnya upaya swasembada selama ini, kebijakan nasional yang paling masuk akal adalah mengembangkan bahan baku non tebu (khususnya Aren) sebagai kebijakan baru swasembada gula nasional.
Skema alur pikir diatas adalah langkah dalam pemetaan sasaran, yaitu membangun swasembada gula. Menurut Nugraha MQ. (2012 : 11.21), pemetaan sasaran adalah teknik yang digunakan untuk menyusun tujuan dan sasaran dan hubungannya dengan alternatif kebijakan. Tujuan, sasaran dan alternatif yang telah diidentifikasikan dengan satu atau dua metode perumusan kebijakan) dapat digambarkan dalam pohon sasaran (objective tree). Maka pola pikir itu menjadi sebagaimana gambar 6 berikut ini

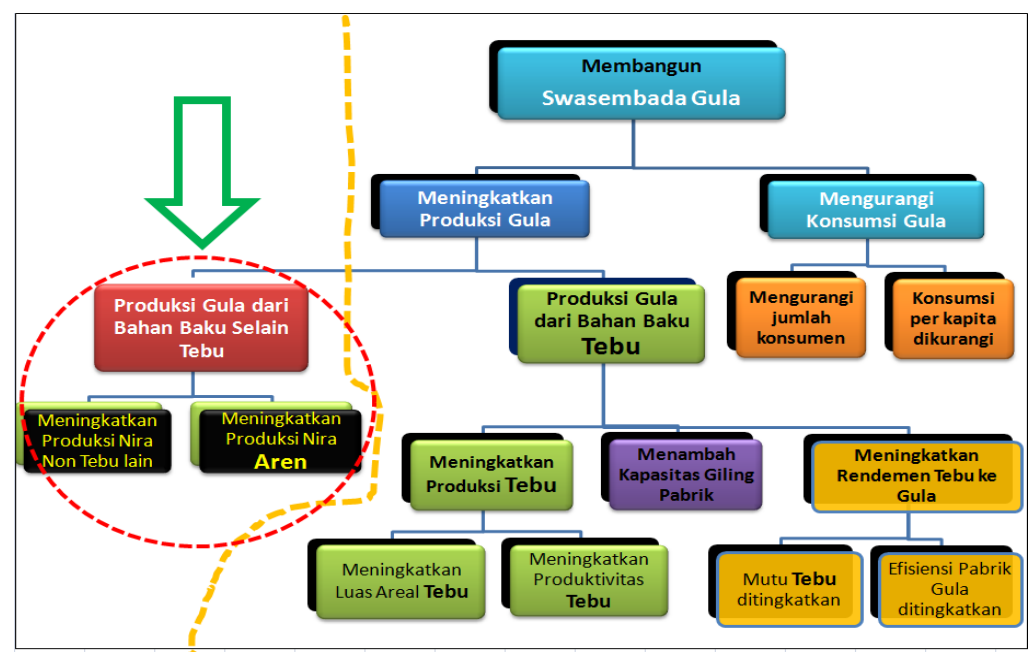

Gambar 6. Skema alur pikir upaya membangun swasembada gula berbasis tebu dan bahan baku non tebu. 
Untuk merangsang semakin banyaknya lembaga yang meneliti, mengkaji, melakukan studi dan mengembangkan Aren, maka perlu adanya insentif dari pemerintah. Insentif dan kemudahan juga diberikan kepada investor pelopor yang mengembangkan industri gula berbasis Aren, baik dari aspek hulu seperti pengembangan pembibitan dan budidaya, sampai aspek hilir seperti pengolahan dan pemasannya. Para peneliti yang ada dan bahkan yang berjasa mengembangkan Aren, baik yang berasal dari lembaga resmi pemerintah maupun dari swasta, patut mendapatkan insentif dan penghargaan. Hal ini penting untuk memecahkan faktor penghambat dominan yaitu kurangnya informasi (IPTEK) dan hasil-hasil penelitian tentang Aren. Demikian juga adanya insentif dan kemudahan investor pelopor akan semakin banyak menarik minat orang lain berinvestasi di pengembangan Aren.

\section{SIMPULAN DAN SARAN}

Dari hasil dan pembahasan penelitian ini penulis dapat menyimpulkan bahwa peluang untuk pengembangan industri gula Aren dalam mendukung swasembada gula nasional jangka panjang adalah sangat berpeluang besar. Pengembangan industri gula Aren dapat dijadikan kebijakan alternatif yang diyakini akan memberi harapan besar dalam mendukung swasembada gula nasional, dan mensejahterakan para pelakunya. Hasil penelitian ini menunjukkan bahwa upayaupaya pemerintah selama ini sudah banyak dilakukan untuk tercapainya swasembada gula nasional, namun demikian hasilnya masih jauh dari harapan. Upaya peningkatan produksi tebu terkendala dengan sulitnya mengembangkan luas areal tanam, menurunnya produktivitas tebu dan kesuburan lahan. Pabrik gula yang sudah berumur sangat tua juga belum mampu diganti dengan pembangunan pabrik gula baru yang memerlukan investasi sangat besar. Keadaan ini menyebabkan inefisiensi dan rendemen gula dari tebu hasil panen yang semakin menurun. Sementara itu keadaan pergulaan dunia juga masih mendistorsi ekonomi gula dalam negeri, menyebabkan keadaan yang sulit diprediksi secara jangka panjang jika impor gula tetap berlangsung. Sehingga jika ingin berswasembada gula maka harus membuka alternatif kebijakan baru dengan komoditi selain tebu memiliki prospek ekonomi lebih bagus, yaitu Aren.

Hambatan yang mungkin akan dihadapi dalam pengembangan industri Aren ini adalah adanya anggapan dan mitos yang salah tentang pohon Aren, yaitu Aren hanya untuk gula merah tradisional dan minuman keras. Belum adanya program dan lembaga pemerintah yang serius menjadi kendala dalam pengembangan komoditi Aren. Penguasaan teknologi dan keterbatasan yang dialami oleh para petani Aren selama ini menyebabkan usaha Aren sulit berkembang dan berdaya saing. Adapun strategi yang bisa dilakukan untuk mengatasi hambatanhambatan ini, ialah (i) pengembangan industri gula berbasis Aren dengan program kebijakan pemerintah yang mendorong tersedianya informasi, ilmu dan teknologi terbaru tentang Aren, (ii) memberi insentif bagi investor berupa kemudahan perijinan dan penyediaan lahannya, dan (iii) Pemerintah mulai mengarahkan industri Aren menghasilkan gula kristal putih dan untuk menghasilkan gula organik yang berdaya saing tinggi.

Sedangkan terhadap adanya kekhawatiran akan maraknya minuman keras juga perlu diantisipasi dengan adanya payung hukum, pengawasan dan penegakan hukum. Sosialisasi dan edukasi tentang Aren dengan segala seluk beluknya, termasuk dalam menerapkan sistem perkebunan yang ketat dengan kawalan Perda untuk mengatur, memonitor, mengawasi dan memberikan sangsi atas pelanggaran terhadap peraturan yang 
berlaku. Sedangkan pengembangan perkebunan dan industri Aren oleh BUMN dan pihak Swasta dengan sistem kemitraan yang saling menguntungkan diyakini dapat menjadi pemicu awal pengembangan Aren di Indonesia.

Disarankan kepada Pemerintah Pusat untuk terus mendorong dan mencari alternatif baru bahan baku gula selain tebu, khususnya Aren yang dilakukan lebih serius. Dalam program swasembada gula agar PGPG yang ada diberi kebebasan dan diberi insentif bila mereka mengembangkan komoditi alternatif bahan gula yang berasal dari Aren. Pemerintah Pusat juga disarankan agar mengarahkan Kementerian Riset dan Teknologi, LIPI dan lembaga riset lainnya untuk mencari terobosan dalam menyelesaikan masalah gula nasional, utamanya berbasis Aren. Badan Litbang Pertanian Kementerian Pertanian agar lebih memberikan fokus yang kuat pada Penelitian dan Pengembangan tanaman Aren, seperti membentuk Riset Centre khusus Aren, menyusun Road Map Riset dan Pengembangan Aren, dan menyediaakan anggaran yang memadai untuk implementasinya. Adapun Direktorat Jendral Perkebunan dan yang terkait lainnya untuk mengembangkan Aren dan meresign kebijakan yang ada untuk mendukung swasembada gula nasional dengan basis Aren.

Kepada Pemerintah Daerah agar sudah mulai melakukan kajian tentang pengembangan Aren di daerah, menyiapkan payung hukum seperti Perda dan pendanaan dalam riset, pengembangan dan implementasinya di masyarakat dan dunia usaha. Selanjutnya disarankan untuk menggerakkan Badan Litbang Daerah, Perusda, Dinas Pertanian, Dinas Perkebunan, Dinas Perdagangan dan Perindustrian dan melalui koordinasi Bappeda dan Balitbangda menyusun perencanaan dalam pengembangan perkebunan dan industri gula berbasis Aren di daerah.
Kepada Kementerian BUMN disarankan agar Badan Usaha Milik Negara yang bergerak di industri gula seperti PTPN dan PG-PG, untuk mulai mengkaji alternatif bahan baku Aren, kemudian melakukan penyesuaian atau resign pabrik yang memungkinkan bahan selain tebu bisa diolah dengan pabrik yang ada, sehingga bisa meminimalkan investasi. Universitas dan Perguruan Tinggi disarankan agar mulai mengarahkan pengembangan riset dan penilitian bagi para dosen dan mahasiswa, serta kegiatan pengabdian masyarakat kepada pengembangan Aren sebagai bahan baku gula khususnya dan pengembangan Aren untuk peningkatan kesejahteraan masyarakat.

\section{DAFTAR PUSTAKA}

Anonimous, 2010, Gula Bit Harapan Baru Mencapai Swasembada Gula 2014, Diambil tanggal 16 Februari 2013 dari situs

http://tabloidsinartani.com/Kebun/Gul a-Bit-Harapan-Baru-Mencapai-

Swasembada-Gula-2014.html

Anonimous, 2012. Inovasi Produksi Gula Sorgum Alternatif Menarik. Diambil tanggal 16 Februari 2013 dari situs http://surabaya.tribunnews.com/2012/1 2/17/inovasi-produksi-gula-sorgumalternatifmenarik\#sthash.YoYwV9ic.dpbs

Anonimous, 2012. Gula Aren Sebagai Pemanis Alternatif. Diambil pada tanggal 16 Februari 2013 dari situs : http://www.informasikita.com/201204 15378/Kesehatan/Manfaat-GulaAren/gula-aren-untuk-diabetes.

Anonimous, 2013. Menuju Swasembada Gula Menjaring Gula Dari Sumber Alternatif. Diambil tanggal 16 Februari 2013 dari situs http://astrinuristyami.wordpress.com/2 013/01/30/menuju-swasembada-gulamenjaring-gula-dari-sumber-alternatif/ 
Biro Pusat Statistik. 2011. Produksi Perkebunan Besar Menurut Jenis Tanaman. Biro Pusat Statistik. [Terakhir Diambil: 11 Januari 2011] dari Situs : http://www.bps.go.id/tab_sub/view.p hp?tabel=1\&daftar=1\&id_subyek $=54$ \&notab $=2$

Dian Kusumanto, 2012. Antara Food Estate dan Pengembangan Aren. Diambil pada tanggal 7 Februari 2013 dari Situs World Wide Web : http://ekonomi.kompasiana.com/agrob isnis/2012/11/20/antara-food-estatedan-pengembangan-aren-504748.html

Dian Kusumanto, 2012. Menyongsong Hadirnya Aren Dan Lengsernya Tebu Dari Tahta Industri Gula Nasional. Diambil pada tanggal 7 Februari 2013 dari Situs World Wide Web : http://ekonomi.kompasiana.com/agrob isnis/2012/11/20/MenyongsongHadirnya-Aren-Dan-LengsernyaTebu-Dari Tahta-Industri-GulaNasional-504748.html

Nainggolan K., 2005. Kebijakan Gula Nasional Dan Persaingan Global. Badan Ketahanan Pangan Nasional. Jakarta

Nugraha, M.Q., 2011. Manajemen Strategik Organisasi Publik. Penerbit Universitas Terbuka, Jakarta. Hal : 3.3-3.5.

Rumokoi, MMM., 2004. Aren, Kelapa dan Lontar sebagai Alternatif Pemenuhan Kebutuhan Gula Nasional. Prosiding Seminar Nasional Aren 9 Juni 2004 di Tondano Sulawesi Utara. Hal : 22 30.

Susilo WR. dan Sinaga BM., 2005. Analisa Kebijakan Industri Gula Indonesia, Jurnal Agro Ekonomi, Volume 23 No 1, Mei 2005. Bogor. Hal : 30-53 